\title{
Typology of Pensions in the Republic of Macedonia
}

\author{
Vjollca Sulejmani Asani
}

\begin{abstract}
The Republic of Macedonia has a multidimensional pension system, a pension system which provides and protects the insured during the old age, provides and protects the insured persons in case of disability and provides and protects the insured in case of death. The first part of the pension provides the value of the old-age pension constituted by the $80 \%$ basis of the accumulated amount of contributions paid during the period of work - which is known as pension of the first pillar pension, this pension is provided by the state, by the State institution of Pension and Invalidity Insurance Fund of the Republic of Macedonia. The second part of the old-age pension is provided by accumulated social security savings for so many years of work, while pensions are provided and paid by the private pension company and this type of retirement is known as the pension of the second pillar of pensions. The third part of the pension is a voluntary pension which derives from voluntary old-age savings, this type of pension is known as the third pension of the pillar pension which is provided and paid by the private pension company.Pension reform provides opportunities for citizens of the Republic of Macedonia due to the variety of old age pension and offers to the ones with self-insurance to decide on their own, for the manner and type of the retirement pension.There are different types of pensions: old age pension, disability pension, inheritance pension, cash compensation, professional rehabilitation and minimum pension rights, these types of pensions are provided by the state and are part of the pensions provided by the first pillar of the state.The pensions offered by the private pension company are of a different kind, namely: direct permanent annuity, programmed withdrawal, temporary withdrawal in combination with prolonged permanent annuities, these types of pensions are part of the second pension.Pensions provided by the private pension company for the third pillar are: annuity payment, programmed withdrawal, multiple payment and a combination of the three cases mentioned above.
\end{abstract}

Keywods: Typology, Pensions, Republic of Macedonia

\section{Introduction}

The typology of reformed pension of disability insurance pensions in the Republic of Macedonia from the first pension pillar are: Old-age pension is the right of the insured person when he or she obtains the right to old age pension at the age of 64 for men and 62 for women, with at least 15 years of retirement work experience;

- Disability pension means the right of the insured person who will be incapacitated for work as well as the remaining insured worker who, due to the attainment of a certain age, can not be trained with professional rehabilitation to perform any of the other relevant activities and earn the right to disability pension on the basis of two data,

- $\quad$ Family pension is a family pension that is carried out by the insured and the retirement pension belongs to the spouse, children and parents who are in the categories when the insured person is fed under prescribed legal conditions (nullity, mental and physical psychology, etc.).

- Professional rehabilitation, right which belongs to every insured who is in the category of incompetence for activity and possesses medical documentation for rehabilitation;

- $\quad$ Cash compensation is the right which belongs to any insured person who during the performance of the activity has suffered any physical,

- Lower pension value, the right that is legally determined by the minimum survivor's pension (Current Report of the Invalidity Pension Fund of the Republic of Macedonia).

Types of pension from private pension companies 
There are three types of pensions from private pension companies in the Republic of Macedonia:

1. Retirement pension, which is determined by the monthly average of payments that the insured has realized during the entire insurance period. (The Law on Financial Pension Insurance Capital,, 07-115 / 1/2008, 122)

2. Disability pension- is caused as a result of illness, work-related injuries and occupational illnesses

3. Inherited Pension - There are many ways of organizing the inherited pension. For a spouse, who remains long on one side, there is in principle a need for more than half of the couple's income in order to maintain the standard of living (Dajmond, 2013: 146).

4. Disability-invalidity pension is caused as a result of illness, work-related injuries and occupational illness (Yes).

5. Inherited Pension - There are many ways of organizing the inherited pension. For a spouse who remains long without a pair, there is in principle a need for more than half of the couple's income in order to maintain the standard of living (Dajmond, 2013: 146).

\section{Method of payment of pensions to II Pension pillar:}

Direct permanent annuity, uninterrupted agreement, the insurance company has no right to terminate the annuity policy even in the case of consent by the retirement user (Ibid., Article 41).

programmed withdrawal; In cases where the retirement user has designated programmed withdrawals in combination with a prolonged permanent annuity, he has the right at any moment to replace the provisional programmed withdrawal provided by a pension company, (Ibid., 43).

Temporary Scheduled Retirement in combination with a Prolonged Permanent Annuity (See below).

- Guaranteed annuity is a type of pension, which the insured uses until his death and after his death; the retirement benefit for the guaranteed annuity period is used by the heirs; the duration of this type of pension is up to 240 months or 20 years of pension (Article 5); Fixed annuity with living expenses - the insurance company is obliged to make periodic harmonization of the fixed-rate pension annuity harmonized with the cost of living in two ways; $\square$ Fixed annuity according to the growth of the living expenses index, in the previous semester in relation to the semiannual preceding the expenditures index in the Republic of Macedonia, January 1 and July 1 ;

- Fixed nominal harmonization - The percentage of harmonization is determined on the day of acquisition of the annuity policy and is unchanged during the duration of the policy (lbid, Article 6);

- Pillar II annuity policies are sold by the insurance company through the insurance representative, the insurance representation company, and the insurance brokerage company. (Ibid., Article 9);

For the amount of the pension through fixed income annuity in profit, the insurance company is obliged that during the calculation of the fixed annuity pension to use incentives and projections with allowed parameters

The pension company uses the following parameters when calculating the pension:

- the total amount of funds in the individual account;

- $\quad$ annuity factor for individual pension;

- $\quad$ The age of the pension beneficiary and the income market rate (Ibid., Article 16.2).

The pensioner has the right to use the accumulated funds in the individual account to withdraw the two pensions in combination:

- Temporary scheduled withdrawal and

- Prolonged permanent annuity.

Temporary programmed retirement assets and retirement pension through prolonged annuity are determined through the quotation annuity by the insurance company taking into account the total amount of funds in the individual account, the length of the deferral period and the relative levels of both pensions. There are two ways of retirement only from the second pillar:

- One-off payment of the second pillar pension assets of the financial capital of the pension insurance accumulated in the individual account as pension savings 
- Realization of the pension only from the second pillar, this type comes to life when the pension is higher or equal to $40 \%$ of the lowest amount of pension on the day of the realization of the right to a pension (Ibid.).

\section{Typology of voluntary pension from the third private pension pillar}

Types of Voluntary Pension Compensation - the insurance company and the pension company pays the pension compensation with the use of one of these types of payments according to the choice of the member of the Pension Fund:

- $\quad$ Annuity payment;

- $\quad$ programmed withdrawal;

- Multiple payment

- Combination of the above mentioned three cases (lbid, 68).

There are such types of voluntary pension annuities: Individual and joint annuities, Permanent and temporary annuities, Direct and prolonged annuity, Annuity with guaranteed period and annuity with unsecured period, Fixed annuity, variable and fixed annuity with profit participation (Ibid., Article 52).

Programmed Pension of the Third Pillar Pension - The Pension Company provides these types of programmed pension: permanent programmed withdrawal and programmed temporary withdrawal (Same, 60).

The advantage of the professional pension scheme is that the funds collected from additional contributions can be withdrawn 10 years before retirement, that is, men 54 years and females 52 years (lbid).

When a Pension Fund member acquires the right to a Pension Compensation, the amount of accumulated funds can be utilized in this way:

- Payment of the total amount of the member's account at once or more times

- Purchase of pension annuity paid until the end of life;

- $\quad$ programmed withdrawal of funds;

- Combining the above options. (Ibid, Article 122).

\section{Conclusion}

Specifically, there are different types of retirement pension from the first pillar of state pensions given the category in which they are retired, whereas, unlike the first pillar of the state, the second pillar differs because the self-insured person determines the type of pension and the manner of withdrawing the pension from their savings. Unlike two pension pillars, the third pillar pension allows the pensioner to determine how to withdraw their savings 10 years before retirement as well as to make various combinations that are mentioned in the paper and especially combinations of two or three types of pension.

\section{Literature}

[1] Arza, C. \& Johnson, P. (2004) "the Development of Public Pensions from 1889 to the 1990s", SAGE Discussion Paper No.20.

[2] Abramovici, G. (2003) "the Social Protection in Europe", Eurostat. Statistics in Focus: Population and Social Conditions, No.3

[3] World Bank, FSPIRM Social Security Support Document for 1997; Legal Document Borrowed from MAPAS Archive;

[4] Banking Risk Management and Basel Agreement, 31 May-1 June, 2004 Skopje, Southeast Europe Enterprise Development;

[5] Complementary \& Private Pensions Throughout the World 2003

[6] Law on Pension Fund Financial Capital, 07-115/1/2008

[7] Holzmann, R. (2012) "Global Pension System and Their Reform", Worldwide Drives, Trends and Challenges.

[8] Pendovska Vesna, Razvoj Na Makedonski Kapital, Republic of Macedonia Securities Commission, Makedonska Riznica Kumanovo, 2004 Skopje;

[9] Report on Technical Assistance for Pension Reform FSPIRM, 2002;

[10] Report of Pension System in the Republic of Macedonia, 2001 July Skopje;

[11] Regulatory Risk-Based Supervisors, Skopje 2013; 
[12] Reforming Public Pensions, Sharing Experiences of Transitions and OECD Countries, OECD, Emerging Economics Transition;

[13] Skenderi Nagip. (2007) "World Economy and Politics", Dardania University, Pristina

[14] Pendovska Vesna, Debt of the Macedonian Capital, Republic of Macedonia Securities Commission, Makedonska Riznica Kumanovo, 2004 Skopje;

[15] Report on Technical Assistance of Pension Reform FSPIRM, 2002;

[16] Report of Pension System in the Republic of Macedonia, 2001 July Skopje;

[17] Regulatory Risk-Based Supervisors, Skopje 2013;

[18] Reforming Public Pensions, Sharing Experiences of Transitions and OECD Countries, OECD, Emerging Economics Transition;

[19] Skenderi Nagip. (2007) "World Economy And Politics", Dardania University, Pristina 